\title{
Effect of 1-methylcyclopropene (1-MCP) Treatment under Sub-atmospheric Pressure on the Softening of 'Akatsuki' Peach
}

\author{
Hiroko Hayama*, Akiko Ito and Yoshiki Kashimura \\ Department of Plant Cell \& Environment, National Institute of Fruit Tree Science, NARO, Tsukuba $305-8605$
}

\begin{abstract}
Summary
The effect of 1 -methylcyclopropene $(1-\mathrm{MCP})$ on peach fruit shelf life is very weak, unlike that on other climacteric fruits. In this study, the softening rates of peach fruit after a 12 - $\mathrm{h}$ exposure to $1 \mu \mathrm{L} \cdot \mathrm{L}^{-1}$ of 1 $\mathrm{MCP}$ at 1) atmospheric pressure (1-MCP nor); 2) atmospheric pressure with the induction at sub-atmospheric pressure $(25-29 \mathrm{kPa})(1-\mathrm{MCP}-\mathrm{subA}) ; 3) \mathrm{sub}-$ atmospheric pressure $(29 \mathrm{kPa})$ with the induction at $25-29 \mathrm{kPa}$ $(1-\mathrm{MCP}-\mathrm{subB})$ were compared to that of untreated, control fruit. After a 2 -day ripening period, those in 1$\mathrm{MCP}-\mathrm{subB}$ were firmer than those of other treatments; the fruit of $1-\mathrm{MCP}$-nor and $1-\mathrm{MCP}$-subA also remained firmer than did the control. After a 5-day ripening period, the effects were similar among the treatments; the treated fruit were significantly firmer than control fruit. Our data show that 1-MCP treatment at sub-atmospheric pressure slightly delayed softening of the peach fruit, but the results are deemed to be cost ineffective for practical use, compared to other treated climacteric fruits, such as apple. The ineffectiveness of 1 - MCP in peach fruit cannot be attributed to the lack of its diffusion into the flesh.
\end{abstract}

Key Words: ethylene, firmness, Prunus persica, shelf-life.

\section{Introduction}

Most peach (Prunus persica (L.) Batsch) fruit for the fresh market have the characteristic melting texture and rapidly lose flesh firmness after harvest. This characteristic makes it difficult to handle, ship, and market the fruit. It is, therefore, important to develop a technique that delays the postharvest softening of the fruit.

Climacteric peach fruit exhibit an increase in ethylene production that is associated with changes in texture during ripening. Stony-hard peach fruit, such as 'Manami', produce little ethylene during ripening; they remain firm after harvest and have a longer shelf life than do the ethylene-producing melting or non-melting types of peach fruit (Haji et al., 2001). This suggests that the inhibition of ethylene synthesis or ethylene action on peach fruit may delay the softening process after harvest and improve shelf life.

The ethylene action inhibitor, 1-methylcyclopropene (1-MCP) (Sisler and Serek, 1997), has been shown to delay ripening of climacteric fruits, including apple (Fan et al., 1999), plum (Dong et al., 2002), and persimmon (Nakano et al., 2001). However, the desirable effect of 1 - MCP on peach fruit is relatively weak (Fan et al., 2002; Mathooko et al., 2001). As 1- MCP is thought to act by blocking ethylene receptors and preventing ethylene effects in plant tissues (Sisler and Serek, 1997), it is possible that 1-MCP has difficulty accessing the flesh tissue in peach fruit.

Received; November 8, 2004. Accepted; February 25, 2005

* Corresponding author (Email: hhiroko@affrc.go.jp)
Storage at sub-atmospheric pressure has been reported to prolong shelf life of a wide range of crops (Burg and Burg, 1966) because the treatment reduces ethylene production and respiration rates of the fruit (Kondo et al., 1983). In this study, fruit exposed to 1MCP under normal and sub-atmospheric pressures were analyzed to determine its penetration, to explore means of prolonging shelf life, and to clarify the reason for the weak effects of 1-MCP on peach fruit.

\section{Materials and Methods}

\section{Plant materials and quality analysis}

'Akatsuki' fruit, a commonly grown peach for fresh consumption in Japan that were hand-harvested from a fruit orchard in Nagano, were sorted to eliminate those with defects and obtain samples of uniformly mature fruits of similar shape, size and color development. Flesh firmness of fruit was measured by a penetrometer (Italtest, FT011, $8 \mathrm{~mm}$ diameter tip) Soluble solids content (SSC) and $\mathrm{pH}$ were determined on juice extracted from flesh on opposite paired cheeks by using a refractometer (PR-101, Atago) and a pH meter (pHboy$\mathrm{P} 2$, Shindengen), respectively.

\section{1-MCP treatment}

An atmosphere of 1-MCP was generated by adding powder of Smart Fresh ${ }^{\mathrm{TM}}$ (Rohm and Haas Company) to distilled water. Fruit on the day of harvest were exposed to $1 \mu \mathrm{L} \cdot \mathrm{L}^{-1}$ of $1-\mathrm{MCP}$ for $12 \mathrm{~h}$ in a sealed plastic container, a summary of which is shown in Table 1. For sub-atmospheric pressure, samples were placed in a 
Table 1. A summary of 1-MCP treatments applied to peach fruit.

\begin{tabular}{llcc}
\hline \hline \multirow{2}{*}{ Treatment name } & Injection gas & Application & Air pressure \\
\cline { 3 - 4 } & & Treatment $(12 \mathrm{~h})$ \\
\hline $1-\mathrm{MCP}$ - nor & $1-\mathrm{MCP}^{2}$ & $25-29 \mathrm{kPa}$ & normal atmospheric pressure \\
$1-\mathrm{MCP}-$ subA & $1-\mathrm{MCP}$ & $25-29 \mathrm{kPa}$ & normal atmospheric pressure \\
$1-\mathrm{MCP}-$ subB & $1-\mathrm{MCP}$ & $25-29 \mathrm{kPa}$ & $29 \mathrm{kPa}$ \\
Air-subB & $1-\mathrm{MCP}$ free air & $29 \mathrm{kPa}$ \\
\hline
\end{tabular}

${ }^{2}$ Final concentration in a treatment container was $1 \mu \mathrm{L} \cdot \mathrm{L}^{-1}$.

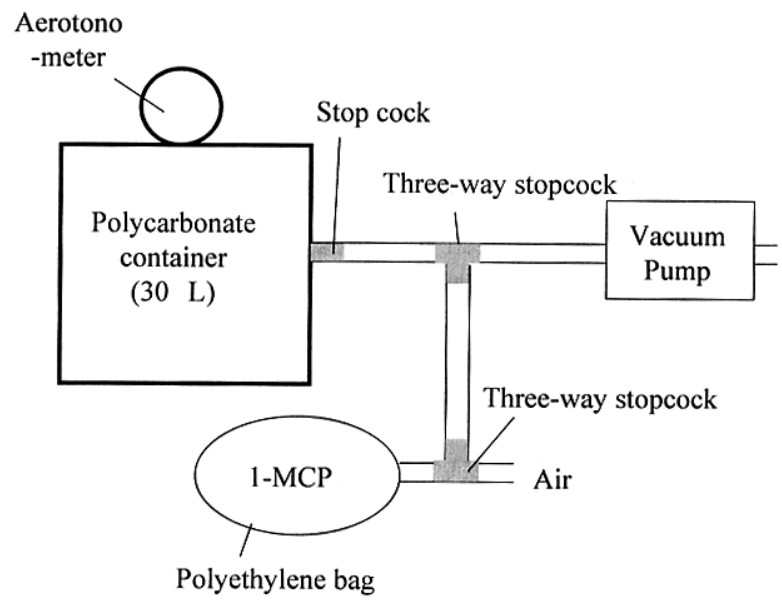

Fig. 1. The 1-MCP treatment system under sub-atmospheric pressure.

pressure tight polycarbonate container (30 L) (Fig. 1). Concentrated 1-MCP gas stock that was prepared in a sealed plastic bag was diluted to get the final concentration of $1 \mu \mathrm{L} \cdot \mathrm{L}^{-1}$ in the container. The pressure in the container was reduced by a vacuum pump (Tokyo Rikakikai Co. Ltd) until the air pressure reached $25 \mathrm{kPa}$. Then, freshly prepared 1-MCP stock was immediately injected into the container, and the pressure in the container was maintained at $29 \mathrm{kPa}$. In the 1-MCP treatment under sub-atmospheric pressure (1-MCPsubA), the container immediately regained its normal atmospheric pressure by introduction of 1- MCP free air and closed by a stopcock. The containers were held with $1 \mu \mathrm{L} \cdot \mathrm{L}^{-1} 1-\mathrm{MCP}$ at normal atmospheric pressure for $12 \mathrm{~h}$. In the other 1-MCP treatment under sub-atmospheric pressure (1-MCP-subB), the container was kept for $12 \mathrm{~h}$ at $29 \mathrm{kPa}$ with $1 \mu \mathrm{L} \cdot \mathrm{L}^{-1} 1$ - MCP without any air injection. For Air sub-atmospheric pressure treatment (Air-subB), fruit were placed in the container and the pressure in the container was reduced to $25 \mathrm{kPa}$ by a vacuum pump and 1-MCP free air was introduced into the container until the pressure reached $29 \mathrm{kPa}$; the container was immediately sealed by a stop cock. The container was held at $29 \mathrm{kPa}$ for $12 \mathrm{~h}$. After all treatments, the containers were opened; the fruit were removed from the containers and ripened at $24^{\circ} \mathrm{C}$ in air. Control fruit were maintained under identical ripening conditions following harvest but without any treatments.

\section{Results and Discussion}

The fruit at harvest had an average of $23.4 \mathrm{~N}$ in flesh firmness, while the juice contained $11.0 \%$ of SSC with $\mathrm{pH}$ 4.4. SSC and $\mathrm{pH}$ were not affected by any treatments tested in this study. Flesh firmness of control fruit decreased rapidly after harvest (Fig. 2) from the initial firmness of $23.4 \mathrm{~N}$ to $4.8 \mathrm{~N}$ and $2.6 \mathrm{~N}$ in 2 and 5 days of ripening, respectively. As $4.0-5.0 \mathrm{~N}$ flesh firmness is considered to be optimum for eating quality of 'Akatsuki' fruit based on sensory evaluation, the fruit became suitable for eating after 2 days of ripening. In 1$\mathrm{MCP}$ - nor treatment, the fruit were slightly firmer than control fruit, that is, $10.9 \mathrm{~N}$ and $4.6 \mathrm{~N}$ after 2 and 5 days of ripening, respectively, although there was no statistical difference after 2 days of ripening. Flesh firmnesses of the fruit treated with 1-MCP-subA or 1-MCPsubB were $16.2 \mathrm{~N}$ and $19.2 \mathrm{~N}$ after 2 days and $4.0 \mathrm{~N}$ and $4.8 \mathrm{~N}$ after 5 days of ripening, respectively. The $1-\mathrm{MCP}$

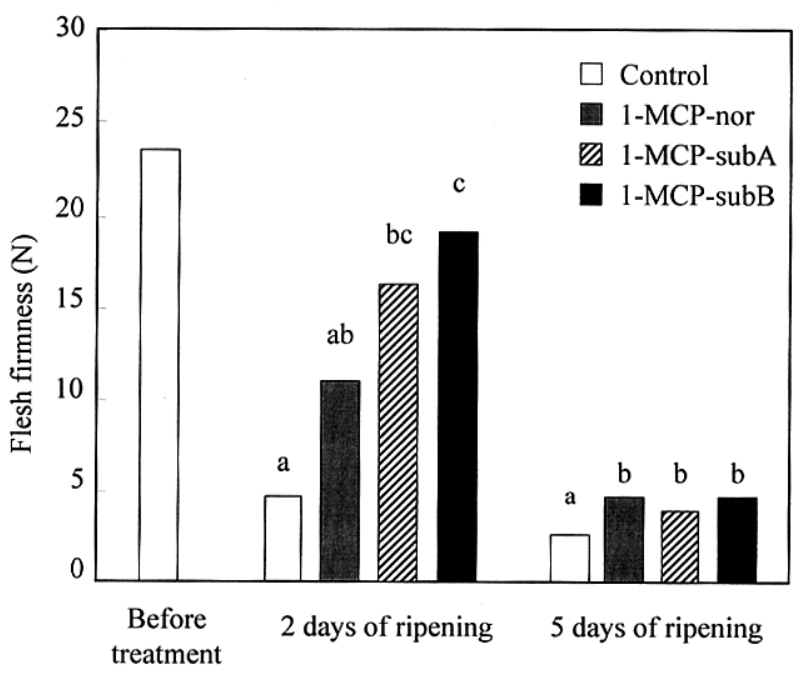

Fig. 2. Flesh firmness of peach fruit treated with $1 \mu \mathrm{L} \cdot \mathrm{L}^{-1}$ 1-MCP for a $12 \mathrm{~h}$ period under normal atmospheric pressure (1- $\mathrm{MCP}-$ nor), under normal atmospheric pressure following the injection under sub-atmospheric pressure $(25-29 \mathrm{kPa})(1-\mathrm{MCP}-\mathrm{subA})$, under sub-atmospheric pressure $(29 \mathrm{kPa})$ following the injection under sub-atmospheric pressure (25-29 $\mathrm{kPa})(1-\mathrm{MCP}$ - subB), and untreated fruit (Control). Different letters show significant difference at $5 \%$ level amongst treatments at the specific stage (Newman-Keuls' Multiple range test). 
subB treatment appeared to be the most effective among the treatments tested in this study because it resulted in significantly firmer fruit than $1-\mathrm{MCP}$ - nor or control, and slightly firmer fruit than $1-\mathrm{MCP}-\mathrm{subA}$ after 2 days of ripening; there was no statistical difference in firmness between 1- MCP-subA and 1- MCPsubB at the end of the 5-day period. Although the storage at sub-atmospheric pressure is known to prolong the fruit shelf life (Burg and Burg, 1966), the fruit stored under sub-atmospheric pressure $(29 \mathrm{kPa})$ for 12 $\mathrm{h}$ without 1 - MCP (Air-subB) did not result in any significant effects on peach fruit shelf life (data not shown). Therefore, the significant delay of the fruit softening shown in 1-MCP-subB treatment was caused by the combination of 1-MCP and sub-atmospheric pressure, not by sub-atmospheric pressure alone.

After 5 days of ripening, $1-\mathrm{MCP}$ - treated fruit (1$\mathrm{MCP}$ - nor, 1-MCP-subA and 1-MCP-subB) became equally suitable for eating although they significantly firmer than control fruit (Fig. 2). The results indicated that the application of 1-MCP under sub-atmospheric pressure was not enough to delay softening for 5 days. The 1-MCP application under sub-atmospheric pressure forced the exchange of gas inside the flesh to 1MCP-containing air; it suggests that diffusion is not the main reason for the weak effect of 1-MCP on peach shelf life.

Our preliminary study showed that ethylene production by $1-\mathrm{MCP}-$ nor, $1-\mathrm{MCP}-$ subA and 1-MCPsubB treated fruit was significantly less than that of untreated fruit (Control and Air-subB) after 5 days of ripening, although there were no differences after 2 days of ripening. However, the effect of the reduced level of ethylene production by $1-$ MCP on the fruit shelf-life was unclear, because fruit softening occurred before 5 days of ripening (Fig. 2).

Our results show that the effect of 1 - MCP under subatmospheric pressure significantly delayed fruit softening after 2 days of ripening, but the effect was still weak compared to that on other climacteric fruits, such as apple (Fan et al., 1999). The weaker effect of $1-\mathrm{MCP}$ on peach fruit is not attributable to the lack of diffusion of 1-MCP into peach flesh, but to other factors, such as binding strength, the amount or turnover of the ethylene receptors in peach fruit. Although this technique of treating 1-MCP under sub-atmospheric pressure was not enough to enhance the shelf-life of peach fruit economically, our findings offer the possibility to improve the effect of 1-MCP on other fruits and shorten the treatment period.

\section{Literature Cited}

Burg, S. P. and E. A. Burg. 1966. Fruit storage at subatmospheric pressures. Science 148: 1190.

Dong, L., S. Lurie and H.-W. Zhou. 2002. Effect of 1methylcyclopropene on ripening of 'Canino' apricots and 'Royal Zee' plums. Postharvest Biol. Technol. 24:
$135-145$.

Fan, X., L. Argenta and J. P. Mattheis. 2002. Interactive effects of 1-MCP and temperature on 'Elberta' peach quality. HortScience 37: 134- 138.

Fan, X., S. M. Blankenship and J. P. Mattheis. 1999. 1methylcyclopropene inhibits apple ripening. J. Amer. Soc. Hort. Sci. 124: 690-695.

Haji, T., H. Yaegaki and M. Yamaguchi. 2001. Changes in ethylene production and flesh firmness of melting, nonmelting, and stony hard peaches after harvest. J. Japan. Soc. Hort. Sci. 70: 458-459.

Kondo, S., C. Oogaki and K. Mim. 1983. Effects of low pressure storage on fruits quality. J. Japan. Soc. Hort. Sci. 52: 180-188 (In Japanese).

Mathooko, F. M., Y. Tsunashima, W. Z. O. Owino, Y. Kubo and Y. Inaba. 2001. Regulation of genes encoding ethylene biosynthetic enzymes in peach (Prunus persica L.) fruit by carbon dioxide and 1-methylcyclopropene. Postharvest Biol. Technol. 21: 265-281.

Nakano, R., S. Harima, E. Ogura, S. Inoue, Y. Kubo and A. Inaba. 2001. Involvement of stress-induced ethylene biosynthesis in fruit softening of 'Saijo' persimmon. J. Japan. Soc. Hort. Sci. 70: $581-585$.

Sisler, E. C. and M. Serek. 1997. Inhibitors of ethylene responses in plants at the receptor level-recent developments. Physiol. Plant. 10: 577-582.

\section{減圧下 1-MCP処理がモモ果実の貯蔵性 に及ぼす影響}

羽山裕子・伊東明子・樫村芳記

(独) 農業・生物系特定産業技術研究機構果樹研究所 305-8605 つくばオ藤本

\section{摘 要}

一般に，モモ果実における 1-MCP処理の効果は他のクラ イマクテリック型果実と比べて小さい. そこで，1-MCPの 果実への吸収効率を上げるため, 減压条件下で 1-MCP処理 を行い，眝蔵性に及ぼす影響を調査した．果実を入れた容器 内部を $25 \mathrm{kPa}$ までに減压し, 容器内における濃度が $1 \mu \mathrm{L}$ ・ $\mathrm{L}^{-1}$ となるよう 1-MCPを注入した後, 減压条件 $(29 \mathrm{kPa})$ 下 で 12時間処理した場合 (1-MCP-subB), 常压で 12 時間処理 した果実 $(1-\mathrm{MCP}-$ nor $)$ や無処理の果実に比へ，処理 2 日後 の果肉軟化が有意に抑制された。また，1-MCP-subB 上同 様減左条件下で 1-MCPを注入した後，すぐに外気を導入し 常区に戻して 12 時間処理した果奏 $(1-\mathrm{MCP}-\mathrm{subA})$ において も 1-MCP-norや無処理に比べて果肉軟化がやや抑制され た. 処理 5 日後の果肉硬度は, 1-MCP 処理を行った果実が無 処理の果実に比へて有意に高かったが，1-MCPの処理方法 間には有意な差が認められなかった．本試験の結果より，減 正条件下における 1-MCP処理はモモ果実に対する処理効果 を若干高めることが明らかとなった。しかしながら，減圧条 件下における処理効果もリンゴ等他のクライマクテリック型 果実に比べて小さく実用的には不十分であると考えられた. モモ果実において 1-MCPの処理効果が小さい原因は，果実 内部への 1-MCP 拡散量の差ではないと考えられる. 